\title{
Factors influencing trust and behavioral intention to use Airbnb service innovation in three ASEAN countries
}

\author{
Evelyn Lim Chua
}

The Graduate School, University of Santo Tomas, Manila, Philippines

\author{
Jason Lim Chiu \\ Department of Business Administration, \\ University College of Business Administration, Daegu, \\ Republic of Korea, and \\ Candy Lim Chiu \\ College of Business and Public Management, \\ Kean University - Wenzhou Campus, Wenzhou, China
}

\begin{abstract}
Purpose - The sharing economy is described as a community marketplace, particularly home sharing such as Airbnb, which is more prevalent. Airbnb changed the way renters and tourists find places to stay when they are traveling. The company introduced innovations in business models and technologies. So, Airbnb requires specific factors that will influence consumers' trust because consumers intuitively seek out trusting factors to make judgments on innovative service providers. Thus, the purpose of this study is to understand the factors that influence travelers' trust to use Airbnb within the three ASEAN nations.

Design/methodology/approach - The data were collected from both qualitative and quantitative methods. The questionnaire was the main data-gathering instrument used in this study and supplemented by informal interviews. A self-administered questionnaire was provided to 130 Airbnb users from the Philippines, Indonesia and Singapore using Hayes' Process Macro as the statistical tool.

Findings - The correlation test was carried out to determine the strength and relationships among the independent, mediating and dependent variables. All independent variables are positively correlated with the mediating variable. The results reveal that ease of use, convenience, information social influence, normative social influence and security have a significant impact on trust and behavioral intention to use Airbnb.

Originality/value - This study contributes to the field of sharing economy, particularly home sharing, by examining different factors that influence trust and behavioral intention. This study focused on the case of Southeast Asian consumers, so this study is useful for marketing practitioners to enhance their marketing strategies in catering to this segment of the market.
\end{abstract}

Keywords Innovation, Sharing economy, Trust, Airbnb, Behavioral intention

Paper type Research paper

(c) Evelyn Chua, Jason Lim Chiu and Candy Lim Chiu. Published in Asia Pacific Journal of Innovation and Entrepreneurship. Published by Emerald Publishing Limited. This article is published under the Creative Commons Attribution (CC BY 4.0) licence. Anyone may reproduce, distribute, translate and create derivative works of this article (for both commercial and non-commercial purposes), subject to full attribution to the original publication and authors. The full terms of this licence may be seen at http://creativecommons.org/licences/by/4.0/legalcode

Received 28 December 2019 Revised 28 February 2020

2 March 2020

11 April 2020

16 May 2020

Accepted 17 May 2020 
APJIE

14,2

\section{Introduction}

The emergence of the sharing economy has changed the buying habit of consumers as everything can now be accessed through smartphones. It has disturbed conventional economic practices, significantly once combined with digital platforms (Malik and Ahsan, 2019). This growing economy catches attention to different industries because it sits at the intersection of two major technological revolutions - digitalization and arranged sharing (Yuana et al., 2019; Han and Rhim, 2019).

Botsman and Rogers (2010) defined the sharing economy as an economic system based on sharing underused assets or services, for free or for a fee, directly from individuals. The sharing economy is an economic system in which assets or services are shared among private individuals, either free or a fee, typically by means of the internet. Sharing economy has developed to become an innovative hybrid business model fit for economies of scale because of the advancement of smartphones, improvement of the internet and involvement of consumers through social media, which enable peer activities among strangers (Sung et al., 2018). Among the well-known brands of the sharing economy players, Airbnb is recognizable for its accommodation sharing (Yang et al., 2019). Over the period of 2010-2015, Airbnb's growth increases 115 times (Koh and King, 2017).

The tourism activities in Southeast Asia have grown tremendously as a tourism body, and the government has heavily invested in tourism campaigns and infrastructure development. Airbnb has recreated travel accommodation by providing guests with localized experience (Gunasekaran and Anandkumar, 2012). Southeast Asian consumers are fond of the online community, as it addressed their needs and wants in an instant. The usage of Airbnb for tourism in the countries has increased because of the positive influence of millennials who are the greatest supporters of the success of the homesharing economy.

The purpose of this study is to know the different factors that persuade travelers from the Philippines, Singapore and Indonesia to trust and use Airbnb. This research fills in the gap by expanding and formulating a deeper understanding of the antecedents of trust that influence consumer behavioral intention to use Airbnb. The results of this study may be useful for Airbnb company, Airbnb hosts, practitioners in the sharing economy industry and marketers by effectively identifying specific factors that influence consumer behavior.

The paper is organized as follows. Section 2 reviews the relevant literature and presents the main hypotheses. Section 3 discusses the empirical methodology and describes the data. Section 4 presents the results. Section 5 concludes with a discussion of the findings.

\section{Literature review and hypotheses development}

Sharing economy

Collaborative consumption or also known as "sharing economy" is the reinvention of typical market behavior through renting, lending, swapping, sharing, bartering and gifting of underused assets through the use of technology (Botsman and Rogers, 2010). However, Belk (2014) definition gave importance to the social and economic movement of sharing idle assets to reduce carbon footprint and contribute to the increase of common interest in society. It signifies a maximization of underused assets by sharing commodities such as cars, homes and utilities with others (Sung et al., 2018). The prominent feature of sharing economy is to give individuals with an economic opportunity to trade their underused assets 
with people through mediators that effectively complements supply and demand through social technology (Petropoulos, 2017).

Intention to use Airbnb service

\section{Innovation of Airbnb}

Airbnb is one of the most successful home-sharing platforms in the field of accommodation (Gutierrez et al., 2016). Airbnb started in San Francisco with the idea of Joe Gebbia and Brian Chesky to rent their remaining room to generate extra income during the major conference (Owyang et al., 2013). According to Guttentag (2015), Airbnb defines its operation as a trusted online community marketplace for people to list, discover and book unique accommodations around the world. It allows people to rent their residential units on a shortterm basis (Konrad and Mac, 2014; Lashinsky, 2015; Martin, 2015; Stollery and Jun, 2017). Airbnb is regarded as a disruptive innovator in the tourism industry and offers a hybrid business model based on modern technologies, and its distinct appeal is focused on costeffectiveness and exceptional local experience (Guttentag, 2015). Compared to the conventional business models that directly connect the suppliers with the consumer such as Hotels.com or Trivago, the Airbnb business model provides an alternative platform to connect people directly which involve the hosts and travelers who wish to exchange their accommodation (Gutierrez et al., 2016).

\section{Behavioral intentions}

The theory of reasoned action (TRA) was developed by Fishbein and Ajzen (1975) to explain the psychological reason for an individual's intended behavior to conduct a conscious act. TRA describes how a person will probably perform to an action that is based on its attitude and affected by subjective norms (Fishbein and Ajzen, 1975). The attitude and subjective norms are essential elements in studying consumer behavior, as it determines what influences person behavioral intention. Ajzen and Fishbein (1980) have reconstructed the TRA by adding the theory of planned behavior (TPB). Hsu and Huang (2012) explained that TPB describes how people are likely to behave in a particular behavior by believing it will result in a positive outcome (Ajzen, 1985). Perceived behavioral control involves a persons' assessment revolving around its ability to have successful participation toward the focus behavior (Goh et al., 2016; Farrukh et al., 2018; El-Zohiry and Abd-Ebaqy, 2019). The importance of the TRA and TPB is to explain human behavior toward the perceived behavioral intention in participating in a sharing economy such as Airbnb.

\section{Trust}

Consumers generally rely on the different factors to decide on their subsequent behaviors to actual use. Trust has become a new form of currency in sharing network, as the exchanges occur between people. Sharing economy is all about the system of trust, trusting a stranger to share a part of one's house or sharing a ride. It breaks the barriers by building its reputation through a social community that provides familiarity, quality and reputations. It is a crucial success factor in sharing economy, as its transaction revolves around the online exchange (Botsman and Rogers, 2010). Trust can reduce the perceived risk of service sharing (Lamberton and Rose, 2012). This study assessed the relationship between the antecedents and the trust constructs, as well as the influence of trust on consumer behavioral intentions. 
Ease of use. Ease of use is one of the mantras of Airbnb founders. Hence, it is important for them that people are having an easy time accessing the Airbnb website and mobile application. Perceived ease of use is the customer's perception that it would be easy to interact with the site or app (Cheema et al., 2009). Perceived ease of use has a strong influence on the intention to technology acceptance (Juniwati, 2014). Therefore, we hypothesize:

H1. The relationship between ease of use and behavioral intention to use Airbnb is fully mediated by trust.

\section{Convenience}

Today's life is about access. With the growing population of millennials, convenience becomes one factor that leads to sharing economy consumption. It becomes possible as sharing economy process on real-time transaction through the use of smartphones that connects providers and consumers. Today's consumers wanted everything to be fast, in which, if they cannot have it on time, the consumer feels that the system cannot be trusted. Habibi et al. (2017) put importance on convenience, efficiency and, most importantly, access to reaching customer satisfaction. Therefore, it is posited the following hypothesis:

H2. The relationship between convenience and behavioral intention to use Airbnb is fully mediated by trust.

\section{Information social influence}

Informational conformity with social media or electron word-of-mouth is conformity with the evidence of reality provided by others (Myers, 2009). When finding the best choice, they will people seek for more information or testimonies to prove that the service they are getting would be worth it (Kim and Choi, 2016). Hence, the consumer finds knowledge in online peer reviews, feedbacks or ratings. Therefore, we hypothesize:

H3. The relationship between information social influence and behavioral intention to use Airbnb is fully mediated by trust.

\section{Reputation}

In sharing economy, reputation is based on online ratings or review scores in relation to the experienced of the customer who made a transaction. Reputation is a sign of trustworthiness manifested as testimony by other people (Botsman and Rogers, 2010; Nawi et al., 2019; Settembre-Blundo et al., 2018). Guttentag (2015) and Jeon (2017) point out the mechanism of reputation is essential for online transactions where parties have a little previous background of each other. Based on these results, we propose the following hypothesis for this study:

H4. The relationship between reputation and behavioral intention to use Airbnb is fully mediated by trust. 
Normative social influence

Nukpe (2012 claim that intrinsic motivation originates from the individual's natural self, the home or family setting, social or peer pressure or a combination of both. Also, consumers who rely on normative influences are more likely to adhere to the expectations of significant others and seek social approval through the acquisition of products or brands where others view it as acceptable (Chu, 2011). Thus, in social impact theory (Latane and Wolf, 1981), it gave importance to other people's thoughts in influencing another individual behavior to explore new things, especially new technology. Hence, we hypothesize:

H5. The relationship between normative social influence and behavioral intention to use Airbnb is fully mediated by trust.

\section{Security}

Security is the number one concern when it comes to technology. Consumers are afraid of identity theft and credit card fraud, as these are the usual hacks that consumers may experience when they share information on an online site. Security such as privacy risk refers to the potential malicious collection and use of users' personal data by sharing economy platform providers (Gao et al., 2015). In which, participating in sharing economy requires to input detailed personal information, which is a significant concern among users (Ballus-Armet et al., 2014). While this is a big issue for sharing economy, somehow, it has broken the wall of mistrust in which consumers opt to continue to participate in the sharing system by screening and verifying its users and collaborators to protect one another. Scholars believed that good security improves trust (Alrawabdeh et al, 2012; Kima et al, 2010). Hence, we hypothesize:

H6. The relationship between security and behavioral intention to use Airbnb is fully mediated by trust.

Based on this discussion, this study analyzes how the identified variables affect trust in using Airbnb. Figure 1 illustrates the conceptual model for this study.

\section{Methodology}

Research design

The data were collected from both qualitative and quantitative methods. The questionnaire was the main data-gathering instrument used in this study and was supplemented by informal interviews. The first part of data gathering is qualitative analysis. It was performed

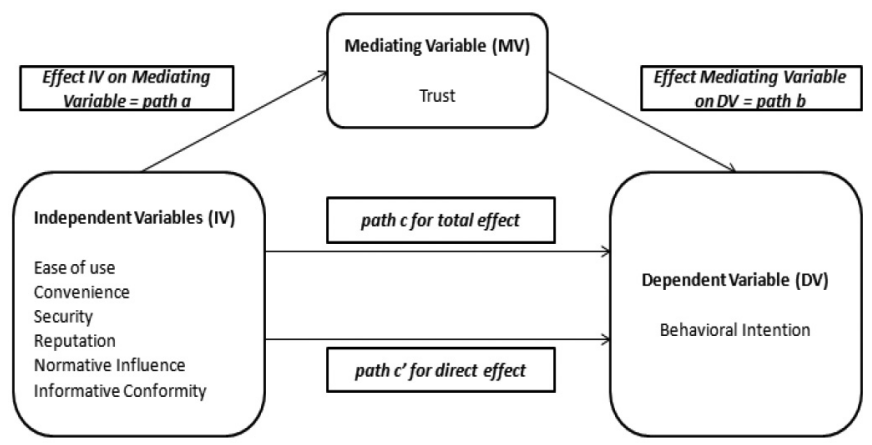

Figure 1. Conceptual framework
Intention to use Airbnb service 
APJIE

14,2

180

by reviewing past related literature and analyzing Airbnb user online reviews with a goal of understanding consumer behavior of Airbnb. The second part of the data gathering focuses on a quantitative analysis through the use of a survey. It was conducted based on previous research that was pre-tested by previous authors and modified to align for this research. Forty-two questions were developed. The variables in this study were measured by a fivepoint Likert scale, ranging from strongly disagree (1) to strongly agree (5).

\section{Research sample}

The samples were taken from Manila, Jakarta and Singapore. These cities in Southeast Asia are the main areas with high Airbnb penetration. A total of 400 questionnaires was deployed in Manila, Singapore and Jakarta. During the data collection process, only 200 surveys were returned and only 130 were valid, which is beyond the minimum sample size required. The self-administered questionnaires were gathered from September 2018 until January 2019 in the major cities involved, having respondents with age at least 20 years old and above and have used Airbnb services at least once. Table 1 lists the demographic information of the respondents.

Taken from the framework of Green (1991), to make the study valid, a regression or correlation analysis was conducted with no less than 50 respondents were gathered with the number increase by the total number of independent variables or the predictors of dependent variables. The formula of Green (1991) suggests that when using the multiple $R^{2}$, the formula is $\mathrm{N}>50+8 \mathrm{p}$ (where $p$ is the total independent variables). However, using when using the beta weights for the multiple correlations or regression analysis, the formula is $\mathrm{N}>104+p$, as shown in Table 1 .

\begin{tabular}{|c|c|c|c|c|c|}
\hline Country & Indonesia & Philippines & Singapore & Total & $(\%)$ \\
\hline Sample size & 27 & 60 & 43 & 130 & 100 \\
\hline $\begin{array}{l}\text { Gender } \\
\text { Male } \\
\text { Female }\end{array}$ & $\begin{array}{l}14 \\
13\end{array}$ & $\begin{array}{l}24 \\
36\end{array}$ & $\begin{array}{l}11 \\
32\end{array}$ & $\begin{array}{l}49 \\
81\end{array}$ & $\begin{array}{l}37.7 \\
62.3\end{array}$ \\
\hline $\begin{array}{l}\text { Age } \\
20-25 \\
26-30 \\
31-35 \\
36-40 \\
\text { Above } 40\end{array}$ & $\begin{array}{r}10 \\
7 \\
3 \\
3 \\
4\end{array}$ & $\begin{array}{r}14 \\
16 \\
15 \\
8 \\
7\end{array}$ & $\begin{array}{r}23 \\
4 \\
7 \\
5 \\
4\end{array}$ & $\begin{array}{l}47 \\
27 \\
25 \\
16 \\
15\end{array}$ & $\begin{array}{l}36.2 \\
20.8 \\
19.2 \\
12.3 \\
11.5\end{array}$ \\
\hline $\begin{array}{l}\text { Marital statu } \\
\text { Single } \\
\text { Married }\end{array}$ & $\begin{array}{r}18 \\
9\end{array}$ & $\begin{array}{l}37 \\
23\end{array}$ & $\begin{array}{r}34 \\
9\end{array}$ & $\begin{array}{l}89 \\
41\end{array}$ & $\begin{array}{l}68.5 \\
31.5\end{array}$ \\
\hline $\begin{array}{l}\text { Educational } \\
\text { Bachelor } \\
\text { Master } \\
\text { Doctorate }\end{array}$ & $\begin{array}{r}\text { nt } \\
20 \\
6 \\
1\end{array}$ & $\begin{array}{r}57 \\
2 \\
1\end{array}$ & $\begin{array}{r}39 \\
4 \\
0\end{array}$ & $\begin{array}{r}116 \\
12 \\
2\end{array}$ & $\begin{array}{r}89.2 \\
9.3 \\
1.5\end{array}$ \\
\hline $\begin{array}{l}\text { Annual incon } \\
\text { Below } 10 \mathrm{k} \\
10 \text { to } 20 \mathrm{k} \\
20,001-30 \mathrm{k} \\
30,001-40 \mathrm{k} \\
\text { Above } 40 \mathrm{k}\end{array}$ & $\begin{array}{r}D \\
17 \\
5 \\
2 \\
3 \\
0\end{array}$ & $\begin{array}{r}18 \\
14 \\
11 \\
15 \\
2\end{array}$ & $\begin{array}{r}29 \\
7 \\
0 \\
4 \\
3\end{array}$ & $\begin{array}{r}64 \\
26 \\
13 \\
22 \\
5\end{array}$ & $\begin{array}{l}49.2 \\
20 \\
10 \\
16.9 \\
3.9\end{array}$ \\
\hline
\end{tabular}

Table 1.

Respondent's demographic profile 


\section{Reliability}

Reliability has been tested using Cronbach's alpha. The findings show that all independent variables have high reliability ranges from 0.735 to 0.931 , which exceeds the minimum acceptable alpha value of 0.7 , as shown in Table 2 . All of the variables have acceptable values. According to Nunnally (1978), if the value of alpha is closer to 1, the higher the internal consistency and reliability of the instrument are. Hence, no indicators were excluded (Table 3).

\section{Correlation test}

The correlation test was carried out to determine the strength and relationships among the independent, mediating and dependent variables. All independent variables are positively correlated with mediating variable. As shown in Table 5 , the result shows that there is a positive correlation between ease of use and trust $(r=0.700, p<0.01)$, between convenience and trust $(r=0.775, p<0.01)$, between information social influence and trust $(r=0.787, p<$ $0.01)$, between reputation and trust $(r=0.787, p<0.01)$, between normative social influence and trust $(r=0.683, p<0.01)$ and between security and trust $(r=0.799, p<0.01)$. Table 5 results also validate that there are positive relationships between independent variables and dependent variable, between ease of use and behavioral intention $(r=0.752, p<0.01)$, between convenience and behavioral intention $(r=0.797, p<0.01)$, between information social influence and behavioral intention $(r=0.746, p<0.01)$, between reputation and behavioral intention $(r=0.772, p<0.01)$ and between security and behavioral intention $(r=$ $0.813, p<0.01)$. Independent variable such as normative social influence shows moderate positive relation with behavioral intention at $(r=0.683, p<0.01)$, while mediating variable trust shows strong positive correlation with behavioral intention at $(r=0.866, p<0.01)$ (Table 4).

\section{Mediation test}

The mediation analysis is based on Baron and Kenny's (1986) framework for evaluating the mediating effect. Multiple path-analytic regressions were conducted to find the direct and indirect influence magnitude relating to each variable. Figure 2 provides the meditational effect of Baron and Kenny (1986).

\begin{tabular}{|c|c|c|}
\hline Green model (1991) & Airbnb users & \\
\hline $\begin{array}{l}\left.\text { (Multiple } R^{2}\right) \mathrm{N}>50+8 \mathrm{p} \\
\text { (Beta weights) } \mathrm{N}>104+p\end{array}$ & $\begin{array}{l}N>50+8(6)=98 \\
N>104+6=110\end{array}$ & $\begin{array}{r}\text { Green model - } \\
\text { sample size }\end{array}$ \\
\hline
\end{tabular}

\begin{tabular}{|c|c|c|}
\hline Variables & No. of items & Cronbach's alpha \\
\hline Ease of use (EU) & 5 & 0.829 \\
\hline Convenience (C) & 5 & 0.909 \\
\hline Information social influence (IS) & 5 & 0.917 \\
\hline Reputation (R) & 3 & 0.797 \\
\hline Normative social influence (NS) & 3 & 0.735 \\
\hline Security (S) & 4 & 0.916 \\
\hline Trust (T) & 4 & 0.876 \\
\hline
\end{tabular}

Intention to use Airbnb service 


\begin{tabular}{|c|c|c|c|c|c|c|c|c|c|}
\hline $\begin{array}{l}\text { APJIE } \\
14 ?\end{array}$ & Variable & $\mathrm{EU}$ & $\mathrm{C}$ & IS & $\mathrm{R}$ & NS & S & $\mathrm{T}$ & $\mathrm{BI}$ \\
\hline \multirow{4}{*}{14,2} & Ease of use (EU) & 1.00 & - & - & - & - & - & - & - \\
\hline & Convenience (C) & $0.828 * *$ & 1.00 & - & - & - & - & - & - \\
\hline & Information social influence (IS) & $0.858^{* *}$ & $0.891^{* *}$ & 1.00 & - & - & - & - & - \\
\hline & Reputation (R) & $0.736^{* *}$ & $0.743^{* *}$ & $0.751^{* *}$ & 1.00 & - & - & - & - \\
\hline \multirow{3}{*}{182} & Normative social influence (NS) & $0.365^{* *}$ & $0.484^{* *}$ & $0.501^{* *}$ & $0.573 * *$ & 1.00 & - & - & - \\
\hline & Security (S) & $0.703 * *$ & $0.763^{* *}$ & $0.720 * *$ & $0.720^{* * *}$ & $0.568 * *$ & 1.00 & - & - \\
\hline & $\begin{array}{l}\text { Trust }(\mathrm{T}) \\
\text { Behavioral intention }(\mathrm{BI})\end{array}$ & $\begin{array}{l}0.700^{* *} \\
0.752^{* *}\end{array}$ & $\begin{array}{l}0.775^{* *} \\
0.797^{* *}\end{array}$ & $\begin{array}{l}0.787^{* *} \\
0.746^{* *}\end{array}$ & $\begin{array}{l}0.787 * * \\
0.772 * *\end{array}$ & $\begin{array}{l}0.683^{* *} \\
0.566^{* *}\end{array}$ & $\begin{array}{l}0.799 * * \\
0.813^{* *}\end{array}$ & $\begin{array}{l}1.00 \\
0.866 * *\end{array}$ & $\begin{array}{c}- \\
1.00\end{array}$ \\
\hline
\end{tabular}

Table 4.

Notes: ${ }^{* *} p<0.01 ; * p 0.05$

Figure 2.

Mediation model by Baron and Kenny (1986)

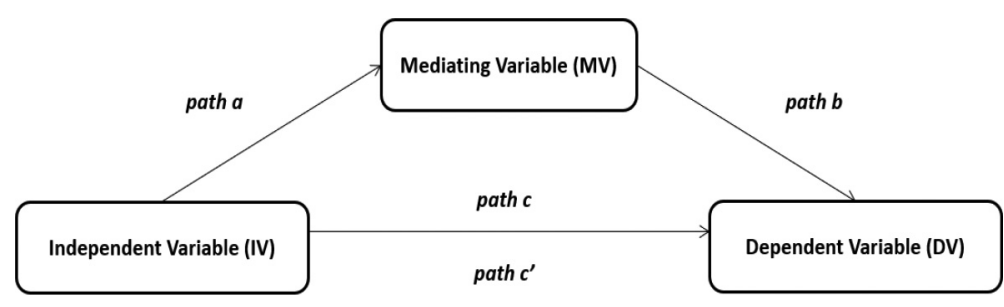

A mediation analysis was conducted using Hayes' Process Macro (Model 4). Trust as the mediator has been input as covariates into Hayes' Process Macro. In total, 5,000 biased bootstrap samples were done to find the approximate standard errors; finding reflects a 95\% confidence interval. Table 5 shows that in Path $c$, there are significant direct effect of five independent variables with dependent variable, behavioral intention to use Airbnb, ease of use $\left[\mathrm{F}(2,127)=211.30, p<0.01, R^{2}=0.77\right]$, convenience $[\mathrm{F}(2,127)=231.12, p<0.01$, $\left.R^{2}=0.78\right]$, informational social influence $\left[\mathrm{F}(2,127)=198.01, p<0.01, R^{2}=0.75\right]$, normative social influence $\left[\mathrm{F}(2,127)=197.92, p<0.01, R^{2}=0.76\right]$ and security $[\mathrm{F}(2,127)=217.47, p<$ $\left.0.01, R^{2}=0.77\right]$, while reputation $\left[\mathrm{F}(2,127)=190.69, p<0.0945, R^{2}=0.75\right]$ does not show any significance relationship. Therefore, we conclude that all independent variables have a direct effect on the dependent variable except reputation at $p<0.01$. The regression analysis in Path $a$ confirmed a positive relationship between independent variables and trust as a mediating variable, without the presence of behavioral intention at $p<0.01$. In Path $b$, the result shows that trust, being the mediator, has been positively linked to the behavioral intention of the user. Table 5 presents that the results in Path $c$ show the total effect of all the Path from Path $a$ (between independent variables and mediating variable) to Path $b$ (between mediating variable and dependent variable) are statistically significant. Therefore, this study concluded that $\mathrm{H1}, \mathrm{H} 2, \mathrm{H} 3, \mathrm{H} 4, \mathrm{H} 5$ and H6 are supported.

Table 6 shows the result of the Sobel analysis to present a measure of the indirect impact of independent variables on the dependent variable through the mediating variable. The result of Path $a$ and Path $b$ or $a b$ (Preacher and Hayes, 2004) is the indirect impact of independent variables on the dependent variable was explained. As a rule, $a b$ $=c-c^{\prime}$ can be fragmented into a direct element of Path $c^{\prime}$ and an indirect element of Path $a b$, where the total effect of independent variables and dependent variable known as Path $c$ (Sobel, 1982). To see the importance of indirect impact, the lower and upper 


\begin{tabular}{|c|c|c|c|c|c|c|c|}
\hline Path analysis & Coefficient & $\mathrm{SE}$ & $t$ & $p$ & LLCI & ULCI & $\begin{array}{l}\text { Intention to } \\
\text { use Airbnb }\end{array}$ \\
\hline \multicolumn{7}{|l|}{ Pathc } & service \\
\hline Ease of use (EU) & 0.901 & 0.077 & 11.775 & 0.000 & 0.749 & 1.052 & \\
\hline Convenience (C) & 0.822 & 0.055 & 14.934 & 0.000 & 0.713 & 0.931 & \\
\hline Information social influence (IS) & 0.781 & 0.069 & 11.373 & 0.000 & 0.645 & 0.916 & \\
\hline Reputation (R) & 0.853 & 0.062 & 13.759 & 0.000 & 0.730 & 0.976 & \\
\hline Normative social influence (NS) & 0.658 & 0.074 & 8.903 & 0.000 & 0.512 & 0.805 & 183 \\
\hline Security (S) & 0.840 & 0.053 & 15.805 & 0.000 & 0.735 & 0.945 & \\
\hline \multicolumn{8}{|l|}{ Patha } \\
\hline Ease of use (EU) & 0.870 & 0.077 & 11.342 & 0.000 & 0.718 & 1.022 & \\
\hline Convenience (C) & 0.789 & 0.056 & 14.032 & 0.000 & 0.678 & 0.901 & \\
\hline Information social influence (IS) & 0.794 & 0.065 & 12.200 & 0.000 & 0.665 & 0.923 & \\
\hline Reputation (R) & 0.993 & 0.051 & 18.211 & 0.000 & 0.822 & 1.023 & \\
\hline Normative social influence (NS) & 0.643 & 0.073 & 8.811 & 0.000 & 0.499 & 0.788 & \\
\hline Security (S) & 0.846 & 0.050 & 16.977 & 0.000 & 0.747 & 0.944 & \\
\hline \multicolumn{8}{|l|}{ Path b } \\
\hline Ease of use (EU) & 0.718 & 0.061 & 11.698 & 0.000 & 0.597 & 0.840 & \\
\hline Convenience $(\mathrm{C})$ & 0.625 & 0.067 & 9.374 & 0.000 & 0.493 & 0.758 & \\
\hline Information social influence (IS) & 0.754 & 0.065 & 11.538 & 0.000 & 0.625 & 0.884 & \\
\hline Reputation (R) & 0.755 & 0.085 & 8.836 & 0.000 & 0.586 & 0.924 & \\
\hline Normative social influence (NS) & 0.789 & 0.056 & 13.997 & 0.000 & 0.677 & 0.900 & \\
\hline Security (S) & 0.616 & 0.077 & 7.962 & 0.000 & 0.463 & 0.769 & \\
\hline \multicolumn{8}{|l|}{ Pathc' } \\
\hline Ease of use (EU) & 0.276 & 0.076 & 3.656 & 0.000 & 0.127 & 0.425 & \\
\hline Convenience (C) & 0.328 & 0.068 & 4.847 & 0.000 & 0.194 & 0.462 & \\
\hline Information social influence (IS) & 0.182 & 0.071 & 2.564 & 0.012 & 0.042 & 0.322 & \\
\hline Reputation (R) & 0.156 & 0.093 & 1.685 & 0.091 & -0.0277 & 0.340 & Table 5. \\
\hline Normative social influence (NS) & 0.151 & 0.059 & 2.556 & 0.012 & 0.034 & 0.268 & \\
\hline Security (S) & 0.319 & 0.079 & 4.064 & 0.000 & 0.164 & 0.475 & mediation analy \\
\hline
\end{tabular}

\begin{tabular}{lccccccc}
\hline & & & & & & & \multicolumn{2}{l}{$\begin{array}{l}\text { Mediating } \\
\text { Indirect effect }\end{array}$} & Effect & Boot se & Boot LLCI & Boot ULCI & $z$ & $p$ & effect \\
\hline Ease of use (EU) & 0.625 & 0.078 & 0.477 & 0.779 & 8.143 & 0.000 & Yes \\
Convenience (C) & 0.494 & 0.074 & 0.357 & 0.653 & 7.794 & 0.000 & Yes \\
Information social influence (IS) & 0.599 & 0.071 & 0.465 & 0.742 & 8.381 & 0.000 & Yes \\
Reputation (R) & 0.697 & 0.094 & 0.518 & 0.890 & 7.951 & 0.000 & Yes \\
Normative social influence (NS) & 0.506 & 0.076 & 0.353 & 0.649 & 7.460 & 0.000 & Yes \\
Security (S) & 0.521 & 0.079 & 0.369 & 0.683 & 7.210 & 0.000 & Yes
\end{tabular}

Notes: $* p<0.01 ; * * p<0.05$

Table 6.

Test of mediating

boundaries with a confidence interval of $95 \%$ were examined. The indirect effect was significant as zero does not reflect in the confidence interval between the lower limit confidence interval (LLCI) and the upper limit confidence interval (ULCI). Therefore, there is a significant indirect effect on trust as mediator.

In the case of the effect size, a 95\% confidence interval was used for the indirect effect because it was significantly higher than zero. The $p$-value is drawn from the mediated effects, which are equivalent to zero in the population under the assumption of a two-tailed $z$-test. The 
test ratio critical value is \pm 1.96 , which contains $95 \%$ of the normal unit distribution (Preacher and Leonardelli, 2010). Based on Sobel's normal theory test, the calculated $z$ value (z-score) was all above 1.96, which only means that trust mediates between the independent and dependent variables.

\section{Conclusion}

The presence of Airbnb in the hospitality industry has disrupted the traditional business model by taking advantage of technology that provided the innovative experience to consumers. Airbnb growth has shown no sign of slowing down, as it further seeks a wider target market by expanding its operation globally. This study has answered its questions by conducting a survey of the three Southeast Asian cities, namely, Manila, Jakarta and Singapore to understand what are the factors influence Southeast Asian travelers' trust and behavioral intentions to use Airbnb. The result of the study shows that female-single travelers under the age of 20-25 or Generation $Z$ are more susceptible to use Airbnb, followed by the age of $26-30$ who are the millennials. This supports other studies that the younger generations, especially millennials and Generation Z, are the supporters of Airbnb. The result of this study supports the study of Wahono and Endo (2017) and Hwang and Griffiths (2017), who gave importance to millennials as a significant consumer segment in the sharing economy.

The variables were tested using Hayes' Process Macro (Hayes, 2013) and were analyzed using mediation analysis. The results show that there are total effects among independent, mediating and dependent variables. This translates that users of Airbnb can trust the company and use the technology if they find it easy, convenient, secure and information social influence. Furthermore, information social influence played an important part when it comes to trust as this economy relies on social media and previous user's ratings for quality measurement. Goh et al. (2016) and Kwahk and Ge (2012) mentioned that consumers trust Electronic Word-of-Mouth (eWOM) in getting information on a product. While normative influence shows a moderate correlation with trust, this explains that influence coming from friends or family members has a minor influence when it comes to trusting the use of Airbnb. Although reputation does not show a significant direct influence on users, this result shows that consumers can use any home-sharing services as long as they can experience convenience, ease of use, security and gather positive reviews from previous users, friends and family.

The present findings offer a potential study for future research owing to its limitation. Future research can conduct a similar investigation in other Association of Southeast Asian Nations (ASEAN) countries to provide valuable insights into the influences of other nations' respondents toward Airbnb services. An interesting option would be a comparison of all developing ASEAN countries where Airbnb is present. Moreover, because of the limited respondents in this research, it is interesting to do an in-depth analysis by increasing the number of participants to make the result more valid. Furthermore, future research could conduct an exploratory study toward the economic and legal implications of Airbnb to quantify its effect on the nation's GDP and be able to set guidelines to have a fair competition among the hotel industry. Finally, future works should conduct a comparative analysis of other home-sharing services such as PandaBed or Travelio to compare the difference of each homesharing company and to know the reason why consumers prefer other home-sharing services. 


\section{References}

Ajzen, I. (1985), "From intention to action: a theory of planned behavior", in Kuhl, J. and Beckmann, J. (Eds), Action Control: From Cognition to Behavior, Springer-Verlag, New York, NY, pp. 11-40.

Ajzen, I. and Fishbein, M. (1980), "Understanding Attitudes and Predicting Social Behavior", PrenticeHall, Englewwod Cliffs, NJ.

Alrawabdeh, W., Zeglat, D. and Al-zawahreh, A. (2012), "The importance of trust and security issues in e-commerce adoption in the arab world", European Journal of Economics, Finance and Administrative Sciences, Vol. 52 No. 1, pp. 172-178.

Ballus-Armet, I., Shaheen, S.A., Clonts, K. and Weinzimmer, D. (2014), "Peer-to-Peer carsharing: exploring public perception and market characteristics in the San Francisco Bay area, California", Transportation Research Record: Journal of the Transportation Research Board, Vol. 2416 No. 1, pp. 27-36.

Baron, R.M. and Kenny, D.A. (1986), "The Moderator-Mediator variable distinction in social psychological research: conceptual, strategic and statistical considerations", Journal of Personality and Social Psychology, Vol. 51 No. 6, pp. 1173-1182.

Belk, R. (2014), "You are what you can access: sharing and collaborative consumption online", Journal of Business Research, Vol. 67 No. 8, pp. 1595-1600.

Botsman, R. and Rogers, R. (2010), What's Mine is Yours: The Rise of Collaborative Consumption, Harper Collins, New York, NY.

Cheema, U., Rizwan, M., Jalal, R., Durrani, F. and Sohail, N. (2009), “The trend of online shopping in 21st century: impact of enjoyment in TAM model", Asian Journal of Empirical Research, Vol. 3 No. 2 , pp. 131-141.

Chu, S.C. and Kim, Y.J. (2011), "Determinants of consumer engagement in electronic word-of-Mouth in social networking sites", International Journal of Advertising, Vol. 30 No. 1, pp. 44-75.

El-Zohiry, A. and Abd-Ebaqy, K. (2019), "The moderating effect of intrinsic motivation on the relationship between psychological capital and organizational citizenship behaviors", Management Review: An International Journal, Vol. 14 No. 2, pp. 4-32.

Farrukh, M., Alzubi, Y., Shahzad, I., Waheed, A. and Kanwal, N. (2018), "Entrepreneurial intentions: the role of personality traits in perspective of theory of planned behaviour", Asia Pacific Journal of Innovation and Entrepreneurship, Vol. 12 No. 3, pp. 399-414.

Fishbein, M. and Ajzen, I. (1975), Belief, Attitude, Intention, and Behavior: An Introduction to Theory and Research, Addison-Wesley, Reading, MA.

Gao, Y., Li, H. and Luo, Y. (2015), "An empirical study of wearable technology acceptance in healthcare", Industrial Management and Data Systems, Vol. 115 No. 9, pp. 1704-1723.

Goh, S., Ho, V. and Jiang, N. (2016), "The effect of electronic word of mouth on intention to book accommodation via online peer-to-peer platform: investigation of theory of planned behavior", Journal of Internet Banking and Commerce, Vol. 21 No. 1, pp. 1-16.

Green, S.B. (1991), "How many subjects does it take to do a regression analysis?", Multivariate Behavioral Research, Vol. 26 No. 3, pp. 499-510.

Gunasekaran, N. and Anandkumar, V. (2012), "Factors of influence in choosing alternative accommodation: a study with reference to Pondicherry, a coastal heritage town", Procedia Social and Behavioral Sciences, Vol. 62 No. 1, pp. 1127-1132.

Gutierrez, J., Ramonillos, G., Garcia-Palomares, J. and Salas-Olmedo, M. (2016), "Airbnb in tourist cities: comparing spatial patterns of hotels and peer-to-Peer accommodation”, Tourism Management, Vol. 62 No. 1, pp. 278-291.

Guttentag, D. (2015), "Airbnb: Disruptive innovation and the rise of an informal tourism accommodation sector”, Current Issues in Tourism, Vol. 18 No. 12, pp. 1192-1217. 
APJIE 14,2

Habibi, M., Davidson, A. and Laroche, M. (2017), "What managers should know about the sharing economy", Business Horizons, Vol. 60 No. 1, pp. 113-121.

Han, Y. and Rhim, H. (2019), "Impact of platform on customer participation intention: co-creation of open platform and closed platform”, Management Review: An International Journal, Vol. 14 No. 2, pp. 61-70.

Hayes, A.F. (2013), "Introduction to mediation, moderation, and conditional process analysis: a regression-based approach", The Guilford Press, New York.

Hsu, C.H. and Huang, S.S. (2012), "An extension of the theory of planned behavior model for tourist", Journal of Hospitality Management, Vol. 34 No. 3, pp. 255-262.

Hwang, J. and Griffiths, M. (2017), "Share more, drive less: millennials value perception and behavioral intent in using collaborative consumption service", Journal of Consumer Marketing, Vol. 34 No. 2, pp. 132-146.

Jeon, J. (2017), "The impact of brand concept on brand equity", Asia Pacific Journal of Innovation and Entrepreneurship, Vol. 11 No. 2, pp. 233-245.

Juniwati (2014), "Influence of perceived usefulness, ease of use, risk on attitude and intention to shop online”, European Journal of Business Management, Vol. 6 No. 27, pp. 218-229.

Kim, Y. and Choi, J. (2016), "The role of a large competitor's entry and level of innovativeness in consumer adoption of new products: a comparison between market uncertainty and technological uncertainty", Asia Pacific Journal of Innovation and Entrepreneurship, Vol. 10 No. 1, pp. 168-182.

Kima, C., Tao, W., Shin, N. and Kim, S. (2010), "An empirical study of customers' perceptions of security and trust in E-Payment system”, Electronic Commerce Research and Applications, Vol. 9 No. 1, pp. 84-95.

Koh, E. and King, B. (2017), "Accommodating the sharing revolution: a qualitative evaluation of the impact of Airbnb on singapore's budget hotels", Tourism Recreation Research, Vol. 42 No. 4, pp. 409-421.

Konrad, A. and Mac, R. (2014), "Airbnb cofounders to become first sharing economy billionaires as company near $\$ 10$ billion valuation”, Forbes, available at: www.forbes.com/sites/alexkonrad/ 2014/03/20/airbnb-cofounders-are-billionaires/\#33cbaff473e1

Kwahk, K.Y. and Ge, X. (2012), "The effects of social media on e-commerce: a perspective of social impact theory", 45th Hawaii International Conference on System Sciences, pp. 1814-1823.

Lamberton, C. and Rose, R. (2012), "When is ours better than mine? A framework for understanding and altering participation in commercial sharing systems", Journal of Marketing, Vol. 76 No. 4, pp. $109-125$.

Lashinsky, A. (2015), "Uber: an oral history”, fortune, available at: https://fortune.com/2015/06/03/uberan-oral-history/

Latane, B. and Wolf, S. (1981), "The social impact of majorities and minorities", Psychological Review, Vol. 88 No. 5, pp. $438-454$.

Malik, M. and Ahsan, R. (2019), "Toward innovation, co-creation and customers' satisfaction: a banking sector perspective", Asia Pacific Journal of Innovation and Entrepreneurship, Vol. 13 No. 3, pp. 311-325.

Martin, C. (2015), "The sharing economy: a pathway to sustainability or a nightmarish form of neoliberal capitalism?", Ecological Economics, Vol. 121 No. 1, pp. 149-159.

Myers, D.G. (2009), "Using new interactive media to enhance the teaching of psychology (and other disciplines) in developing countries", Perspectives on Psychological Science, Vol. 4 No. 1, pp. 99-100.

Nawi, N., Al Mamun, A., Nasir, N., Abdullah, A. and Mustapha, W. (2019), "Brand image and consumer satisfaction toward Islamic travel packages: a study on tourism entrepreneurship in Malaysia", Asia Pacific Journal of Innovation and Entrepreneurship, Vol. 13 No. 2, pp. 188-202. 
Nukpe, P. (2012), "Motivation: Theory and use in higher education", Investigations in University Teaching and Learning, Vol. 8 No. 1, pp. 11-18.

Nunnally, J.C. (1978), Psychometric Theory 2nd ed, McGraw-Hill, New York, NY.

Owyang, J. Tran, C. and Silva, C. (2013), "The collaborative economy: products, services and market relationships have changed as sharing startups impact business models. To avoid disruption, companies must adopt the collaborative economy value chain", Altimeter Research, available at: https://sharingcitiesalliance.knowledgeowl.com/help/the-collaborative-economy

Petropoulos, G. (2017), "An economic review of the collaborative economy", Policy Contribution, Vol. 5 No. 1, pp. 1-17.

Preacher, K.J. and Hayes, A.F. (2004), "SPSS and SAS procedures for estimating indirect effects in simple mediation models", Behavior Research Methods, Instruments and Computers, Vol. 36 No. 4, pp. 717-731.

Preacher, K.J. and Leonardelli, G.J. (2010), "Calculation for the Sobel test: an interactive calculation tool for mediation tests [online software]", available at: http://quantpsy.org/sobel/sobel.htm

Settembre-Blundo, D., Fernández del Hoyo, A. and García-Muiña, F. (2018), "Hermeneutics as innovative method to design the Brand identity of a nanotechnology company", Asia Pacific Journal of Innovation and Entrepreneurship, Vol. 12 No. 2, pp. 181-205.

Sobel, M.E. (1982), "Asymptotic intervals for indirect effects in structural equations models", Sociological Methodology, Vol. 13 No. 1, pp. 290-312.

Stollery, A. and Jun, S. (2017), "The antecedents of perceived value in the Airbnb context", Asia Pacific Journal of Innovation and Entrepreneurship, Vol. 11 No. 3, pp. 391-404.

Sung, E., Kim, H. and Lee, D. (2018), "Why do people consume and provide sharing economy accommodation? - A sustainability perspective”, Sustainability, Vol. 10 No. 6, p. 2072.

Wahono, F.A. and Endo, W.K. (2017), "Consumer behavior study on the acceptance of Airbnb from consumer in Surabaya, Indonesia", Jurnal Hospitality Dan Manajemen Jasa, Vol. 5 No. 2, pp. 1-15.

Yang, S., Lee, K., Lee, H. and Koo, C. (2019), "In Airbnb we trust: Understanding consumers' trustattachment building mechanisms in the sharing economy", International Journal of Hospitality Management, Vol. 83 No. 1, pp. 198-209.

Yuana, S., Sengers, F., Boon, W. and Raven, B. (2019), "Framing the sharing economy: a media analysis of ridesharing platforms in Indonesia and the Philippines", Journal of Cleaner Production, Vol. 212 No. 1, pp. 1154-1165.

\section{Further reading}

Alrawabdeh, W., Zeglat, D. and Al-Zawahreh, A. (2012), "The importance of trust and security issues in E-Commerce adoption in the Arab world", European Journal of Economics, Finance and Administrative Sciences, Vol. 52 No. 1, pp. 172-178.

Chiu, J., Bool, N. and Chiu, C. (2017), "Challenges and factors influencing initial trust and behavioral intention to use mobile banking services in the Philippines", Asia Pacific Journal of Innovation and Entrepreneurship, Vol. 11 No. 2, pp. 246-278.

Joshua, A.J. and Koshy, M.P. (2011), "Usage patterns of electronic banking services by urban educated customers: Glimpses from India", Journal of Internet Banking and Commerce, Vol. 16 No. 1, pp. 1-12.

Lee, H., Yang, S.B. and Koo, C. (2019), "Exploring the effect of Airbnb hosts' attachment and psychological ownership in the sharing economy", Tourism Management, Vol. 70 No. 1, pp. 284-294.

Ohk, K., Park, S. and Hong, J. (2015), "The influence of perceived usefulness, perceived ease of use, interactivity, and easy of navigation on satisfaction in mobile application", Advanced Science and Technology Letters, Vol. 84 No. 1, pp. 88-92. 
APJIE 14,2

188
Preacher, K.J. and Hayes, A.F. (2008), "Asymptotic and resampling strategies for assessing and comparing indirect effects in multiple mediator models", Behavior Research Methods, Vol. 40 No. 3, pp. 879-891.

PricewaterhouseCoopers LLP (2016), "The sharing economy consumer intelligence series", Available at: $\quad$ www.pwc.com/us/en/industry/entertainment-media/publications/consumer-intelligenceseries/assets/pwc-cis-sharing-economy.pdf

Reuter (2016), “Airbnb seeks funds valuing it at $\$ 30$ billion”, available at: www.reuters.com/article/usairbnb-funding/airbnb-seeks-funds-valuing-it-at-30-billion-source-idUSKCNOZE2FR

Rogerson, P.A. (2001), Statistical Methods for Geography, Sage, London.

\section{Corresponding author}

Jason Lim Chiu can be contacted at: jlc534@gmail.com

For instructions on how to order reprints of this article, please visit our website: 